Utah State University

DigitalCommons@USU

$11-29-2016$

\title{
The best laid plans: Educational innovation in elementary teacher generated integrated STEM lesson plans
}

Christina M. Sias

Utah State University, csias@intechchs.org

Louis S. Nadelson

Colorado Mesa University

Stephanie M. Juth

Utah State University

Anne L. Seifert

Idaho National Laboratory

Follow this and additional works at: https://digitalcommons.usu.edu/teal_stures

Part of the Education Commons

\section{Recommended Citation}

Sias, Christina M.; Nadelson, Louis S.; Juth, Stephanie M.; and Seifert, Anne L., "The best laid plans: Educational innovation in elementary teacher generated integrated STEM lesson plans" (2016). Teacher Education and Leadership Student Research. Paper 1.

https://digitalcommons.usu.edu/teal_stures/1

This Article is brought to you for free and open access by the Teacher Education and Leadership Student Works at DigitalCommons@USU. It has been accepted for inclusion in Teacher Education and Leadership Student Research by an authorized administrator of DigitalCommons@USU. For more information, please contact digitalcommons@usu.edu.

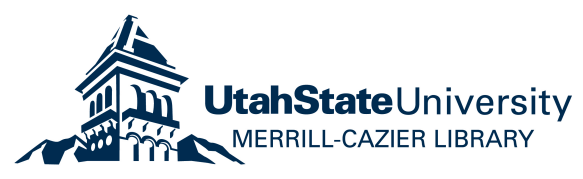




\title{
The Journal of Educational Research
}

\section{The best laid plans: Educational innovation in elementary teacher generated integrated STEM lesson plans}

\author{
Christina M. Sias, Louis S. Nadelson, Stephanie M. Juth \& Anne L. Seifert
}

To cite this article: Christina M. Sias, Louis S. Nadelson, Stephanie M. Juth \& Anne L. Seifert (2016): The best laid plans: Educational innovation in elementary teacher generated integrated STEM lesson plans, The Journal of Educational Research, DOI: 10.1080/00220671.2016.1253539

To link to this article: http://dx.doi.org/10.1080/00220671.2016.1253539

曲 Published online: 29 Nov 2016.

Submit your article to this journal $[\pi$

Џll Article views: 23

Q View related articles $\sqsubset$

View Crossmark data ¿ 


\title{
The best laid plans: Educational innovation in elementary teacher generated integrated STEM lesson plans
}

\author{
Christina M. Sias ${ }^{a}$, Louis S. Nadelson ${ }^{b}$, Stephanie M. Juth ${ }^{a}$, and Anne L. Seifert ${ }^{c}$ \\ ${ }^{a}$ Department of Teacher Education and Leadership, Utah State University, Logan, Utah, USA; ${ }^{\mathrm{b}}$ Colorado Mesa University, Grand Junction, Colorado, USA; \\ 'Science, Technology, Engineering, and Mathematics, Idaho National Laboratory, Idaho Falls, Idaho, USA
}

\begin{abstract}
Students need to be prepared for the 21 st century by developing the literacy skills necessary for participating in the age of synthesis-an age that requires a progressive set of skills and knowledge. The authors identified nine educational innovations that are perceived to be effective for preparing students for the 21 st century age of synthesis society. They coded a collection of 39 teacher-generated Grade 3-5 science, technology, engineering, and mathematics (STEM) lesson plans to document the extent to which the teachers included these nine educational innovations their STEM lesson planning. The authors found practices such as project-based and student-centered learning (which are common established approaches to teaching STEM) to be strongly represented in the plans, whereas practices such as family involvement and place-based learning (which have not been traditionally used in STEM instruction) were less evident in the plans. In their discussion they explore the implications for STEM teaching, and potential directions for future research.
\end{abstract}

ARTICLE HISTORY

Received 24 April 2016

Revised 18 October 2016

Accepted 20 October 2016

\section{KEYWORDS}

Curricular choice; innovation; instructional practices; lesson plans; STEM
Our students need to be prepared for the 21st century by developing the literacy skills necessary for participating in the age of synthesis (see Nadelson \& Seifert (2016) for comprehensive definition) - an age that requires a progressive set of skills and knowledge (Cai, 2011; Hall, 1995). In the past, teachers were seen as dispensers of knowledge, whereas the role of the student was a receiver of knowledge. In this paradigm, students were not expected to be active thinkers or problem solvers but rather providers of the correct answer to teachers' questions (Anderson, 2002). Students today need to be prepared with a different set of skills and process than have been traditionally taught to comprehend and address complex science, mathematics, engineering and technology (STEM) problems such as globalization and the growing number of complex transdisciplinary issues (e.g., clean energy, climate change, effective transportation). Students now need to learn how to remain productive with constantly evolving technology, and identify accurate information in the rapidly expanding abundance of accessible sources (Pearlman, 2010; Saavedra \& Opfer, 2012). There are growing expectations that students enter college and workforce with an array of 21 st century skills (see Table 1), practices, and perspectives (Rotherham \& Willingham, 2010). Thus, there is value in determining the level to which our K-12 curriculum and instruction is preparing students for situations such as effective problem solving-both individually and as members of teams.

Although some researchers recognize the need to align K-12 curriculum and instruction with 21st century expectations (Dede, 2010; Larson \& Miller, 2011), research in the area has typically focused on single facet of preparation, such as use of technology (Kirkwood \& Price, 2005) or project-based learning (Bell, 2010). Yet, to effectively prepare our students with the needed diversity of 21 st century skills, practices, and knowledge, there is justification to consider a wide range of curricular and instructional innovations. We consider curricular and instructional innovations such as innovative teaching practices, course content, and curricular concepts that motivate students to work to generate novel solutions to real-world problems (Nadelson, Seifert, \& Sias, 2015). Students need to be exposed to practices and approaches throughout their K-12 education that are reflective of innovations in society, structures of our culture, and the demands for the age of synthesis (Cai, 2011; Hall, 1995; Trilling \& Fadel, 2009). Thus, we were interested in determining the level to which $\mathrm{K}-12$ teachers envisioned or planned to attend to an array of educational innovations associated with preparing their students with 21 st century skills, practices, concepts, and content that will allow the students to be successful in the age of synthesis.

In our comprehensive search of the extant research we were unable to locate any studies that explicitly examined how teachers envisioned using an array of approaches to prepare the students for the age of synthesis. The studies of educational innovations that we located in our search of the literature reported on teacher use of one or two innovative curricular or instructional approaches (Abd-el-Khalick et al., 2004; Anderson, 2002; Bell, 2010; Binkley et al., 2012; Brown \& Melear, 2006; Fogarty, 1991; Gruenwald \& Smith, 2014; Hannafin \& Land, 1997; Hannafin \& Land, 2012; HiattMichael, 2001; Krajcik \& Blumenfeld, 2006; Rogers \& Abell,

CONTACT Christina M. Sias csias@intechchs.org E Department of Teacher Education and Leadership, Utah State University, 2805 Old Main Hill, Logan, UT $84322-$ 1400 .

(c) 2016 Taylor \& Francis Group, LLC 
Table 1. Educational innovations, definitions, and justification for inclusion.

\begin{tabular}{|c|c|c|}
\hline Innovation & Definition & Justification \\
\hline $\begin{array}{l}\text { Curriculum integration (Honey, } \\
\text { Pearson, \& Schweingruber, 2014; } \\
\text { Nadelson, Seifert, Moll, \& Coats, } \\
\text { 2012) }\end{array}$ & $\begin{array}{l}\text { Integrating curriculum from one content } \\
\text { area into another. }\end{array}$ & $\begin{array}{l}\text { Curriculum integration shows students how content knowledge can be applied } \\
\text { across content areas by giving them the opportunity to use multiple content- } \\
\text { area skill sets to complete an assignment or activity. }\end{array}$ \\
\hline $\begin{array}{l}\text { Integration of instructional } \\
\text { technology (Inan \& Lowther, 2010; } \\
\text { Liu \& Szabo, 2009; Rae \& } \\
\text { Nadelson, under review) }\end{array}$ & $\begin{array}{l}\text { Giving students the opportunities to } \\
\text { actively use tools. }\end{array}$ & $\begin{array}{l}\text { Students who learn how to use tools to solve problems will be better prepared } \\
\text { to meet the technological demands of the } 21 \text { st century college and career } \\
\text { landscape. }\end{array}$ \\
\hline $\begin{array}{l}\text { Family involvement (Dierking \& Falk, } \\
\text { 1994; Berkowitz, Schaeffer, } \\
\text { Maloney, Peterson, Gregor, } \\
\text { Levine, \& Beilock, 2015) }\end{array}$ & $\begin{array}{l}\text { Bridging the gap between home and } \\
\text { school by including family members in } \\
\text { lessons and assignments. }\end{array}$ & $\begin{array}{l}\text { Involving families in STEM activities gives students and families the opportunity } \\
\text { to make connections between content learned at school and skills learned at } \\
\text { home. Students and families who discover and build on these connections } \\
\text { have a valuable opportunity to scaffold content knowledge. }\end{array}$ \\
\hline $\begin{array}{l}\text { Inquiry (Abd-El-Khalick et al., 2004; } \\
\text { Anderson, 2002) }\end{array}$ & $\begin{array}{l}\text { Giving students the opportunity to solve } \\
\text { genuine problems. }\end{array}$ & $\begin{array}{l}\text { Teachers who give students the opportunity to answer authentic questions that } \\
\text { may have more than one answer (rather than prescribed questions) are } \\
\text { presenting a valuable opportunity for students to exercise critical thinking } \\
\text { skills. Applying content knowledge to the solution of authentic problems } \\
\text { presents students with learning similar to those found in college and career. }\end{array}$ \\
\hline $\begin{array}{l}\text { Core STEM practices (Nadelson, } \\
\text { Seifert, \& Hendricks, 2015; } \\
\text { National Governors Association } \\
\text { Center for Best Practices \& Council } \\
\text { of Chief State School Officers, } \\
\text { 2010; NGSS Lead States, 2013) }\end{array}$ & $\begin{array}{l}\text { Core STEM practices are the activities and } \\
\text { processes that align with the authentic } \\
\text { work and skills of scientists, } \\
\text { mathematicians, and engineers. }\end{array}$ & $\begin{array}{l}\text { Knowledge of STEM is more than learning content, it involves understanding of } \\
\text { the practices and activities of associated with the formal process of } \\
\text { exploration and application of STEM knowledge through practices. There are } \\
\text { multiple overlaps in practices of different STEM professionals as well as } \\
\text { practices that are unique to the STEM domains, combined we consider these } \\
\text { to be core STEM practices and because of their recent emphasis-an } \\
\text { educational innovation }\end{array}$ \\
\hline
\end{tabular}

2013; Staples \& Diliberto, 2010). Thus, there is a gap in the literature and a need for more holistic examinations of how teachers envision implementing a range of educational innovations that are likely to foster student development of age of synthesis-aligned skills, knowledge, and practices. We addressed this gap in the literature by examining a collection of teacher-generated STEM lesson plans for levels of implementation of nine different educational innovations.

\section{Educational innovations}

We define educational innovations as instructional approaches or curricular choices that are not typically recognized as being standard components of teacher practice. These approaches are marked by unique processes, tool uses, interactions, and ideas that are detailed further in Table 1 (Messmann \& Mulder, 2011; Nadelson et al., 2015; Thurlings, Evers, \& Vermeulen, 2015). One of the primary goals for the adoption and use of educational innovations is to improve teacher effectiveness and student learning and preparation. Building on our prior research on a range of educational innovations (Nadelson et al., 2015), we have identified nine innovations that we maintain foster student development of age of synthesis skills, knowledge, and practices (see Table 1).

We maintain that when teachers teach by implementing one or a combination of educational innovations, they create the context that engages students in age of synthesis practices, authentic learning opportunities, and application of skills and knowledge that reinforce deep learning. When implemented properly, the conditions afforded by educational innovations motivate students to solve problems independently or collectively, without relying on an instructor to provide step-by-step instructions (Anderson, 2002). The educational innovations summarized in Table 1 can provide students with the opportunity to learn how to use instructional technology (e.g., laptops, scales, thermometers) to answer ill-structured questions in different contexts and using unique applications, while broadening their knowledge and skills for learning and communication 
(Binkley et al., 2012; Hannafin \& Land, 1997). Thus, there is a need for teachers to act as guides or facilitators rather than knowledge dispensers, and create learning contexts in which students learn by solving problems and using tools (Anderson, 2002). Engaging students in learning through educational innovations teaches students how to seize opportunities to apply their understanding and skills to solve a wide range of problems. The use of educational innovations is especially useful to classroom teachers as the application may allow students to demonstrates the transfer and integration of their knowledge from one setting to another (Belmont, 1989; Hannafin \& Land, 1997). Hence, given the high potential benefits for preparing students for the age of synthesis, in which students will be expected to develop these problem-solving skills, there is warrant for empirically documenting how teachers envision the integration of educational innovations in their teaching practices.

Thurlings et al. (2015) present evidence of teacher demographics and workplace-related factors as being influential on teacher adoption of educational innovations. Thus, there is a foundation for understanding of potential influences on teacher consideration of educational innovations. However, as we shared previously there remains a gap in understanding teacher consideration and potential implementation of multiple educational innovations simultaneously. To address this gap in the literature there is a need to determine the extent to which teachers may consider implementing multiple educational innovations simultaneously. We addressed the need for foundational knowledge of teacher implementation of multiple educational innovations simultaneously by examining teacher prepared STEM lesson plans for the presence of current educational innovations and the nature of the planned implementation. Although lesson plans are common artifacts, our comprehensive search of the literature failed to reveal any published research in which lesson plans are considered as data sources to determine how teachers envision teaching using educational innovations in their practice. We assert that a greater understanding of how teachers envision implementing the educational innovations will reveal useful findings regarding the innovations they feel comfortable using, and how they conceive leveraging the innovations in their instructional and curricular choices.

\section{STEM teaching and educational innovations}

Teachers are frequently expected to implement educational innovations when teaching STEM (National Governors Association Center for Best Practices \& Council of Chief State School Officers, 2010; NGSS Lead States, 2013). STEM learning standards associated practices have been developed to guide teachers toward creating learning contexts that engage students in activities and processes that parallel those of STEM professionals, an approach that is arguably very different than traditional methods of teaching STEM (e.g., Wysession, 2015). Social expectations for preparing a STEM-literate society and preparing students for the age of synthesis have led to increased support and motivation for teachers to align their teaching with educational innovations. Because of the expectations for preparing a STEM-literate society, teachers have the support and impetus to implement a range of educational innovations in their STEM lessons. Thus, analysis of teacher developed lesson plans is likely to provide insight into the extent to which teachers might consider educational innovations, and how they propose to teach lessons using the innovations.

One potential barrier to teacher adoption of innovative practices is that teachers may be more comfortable using previously developed curriculum that they feel was successful, rather than experimenting with new practices (Brown, 1988). Many teachers, purposefully or inadvertently, teach their students in the same ways that they themselves were taught (Oleson \& Hora, 2014). Because traditional methods of teaching positioned students as passive receptors rather than active learners (Anderson, 2002), teachers who rely on these methods may be placing their students at a disadvantage by reinforcing engaging in conditions that are rarely valued outside of schools. However, teachers who work to integrate age of synthesis educational innovations into their curriculum and instructional are positioned to change this trend, by preparing their students for a future that requires innovation and integration of ideas.

Teaching STEM has the potential to engage students in the educational innovation of curriculum integration by selecting multidisciplinary topics such as energy or transportation (Honey, Pearson, \& Schweingruber, 2014). STEM provides the ideal context for engaging students in problem solving, critical thinking, tool use, curriculum integration, and an array of other skills due to the potential for exploring complex situations and ill-structured problems, building prototypes, and observing outcomes (e.g., having students determine solutions for cleaning a contaminated water supply). Therefore, STEM provides a context for the educational integration of age of synthesis learning (DeJarnette, 2012).

Given the presence of STEM related issues in all communities, there is opportunity for attending to the educational innovation of place-based learning. Thus, if considered creatively and with an open mind, STEM provides an opportunity to attend to our list of educational innovations (see Table 1), providing both the justification for focus on STEM and for examining the STEM lesson plans of teachers for evidence of how they envision teaching educational innovations.

\section{Teacher-generated lesson plans as data}

Lesson plans are a common artifact that teachers learn to develop in their preparation and rely on throughout their careers to guide their practice (Brown \& Melear, 2006). Novice or preservice teachers use lesson plans to organize their activities, construct their goals, and get feedback from their supervisors, whereas inservice teachers tend to rely less on written and detailed lesson plans as they gain more experience (Kagan \& Tippins, 1992). However, lesson plans can provide an important source of evidence or insight into teacher knowledge, perceptions, and preferred curricular and instructional choices (Jacobs, Martin, \& Otieno, 2008). Lesson plans are valuable data sources when it comes to learning more about curricular and instructional choices because they reflect teacher goals for their lessons. Previous research has relied on lesson plans to learn more about the teacher planning process (Brown, 1988, 1993; McCutcheon, 1980; Yinger, 1980) and teacher practices (Jacobs et al., 2008). Hence, there is justification for examining lesson plans to learn more about how innovative practices are considered in relationship to teachers' curricular and instructional choices. 
Lesson plans are unique artifacts of teacher perceptions and practices because they potentially provide greater insight into teachers' instructional and curricular preferences than perhaps any other publicly available teacher generated artifacts. Many teachers commonly share lesson plans with one another within their school communities, and still others share their lesson plans online for teachers in the broader community to access, making the plans widely and publically accessible (Moore, Treahy, Chao \& Barab, 2000; Robins, 2000). Although many teachers maintain class websites or publish newsletters that may be publicly available (Hiatt-Michael, 2001; Staples \& Diliberto, 2010), we argue that lesson plans offer more insight into teacher curricular and instructional choices than other publically accessible teacher generated resources. Furthermore, teacher generated lesson plans reflect the teachers' curricular and instructional priorities, justifying the evaluation of these artifacts as a way of determining how teachers perceive including educational innovations in their practice.

\section{Teacher adoption of innovative practice}

As shared previously, we draw from our previous work on innovation in which we defined innovative instructional practice as nontraditional or novel pedagogical practices which teachers implement to enhance student learning (Nadelson et al., 2015). For some teachers, it is common practice to experiment with new strategies to improve their instruction. Aligned with our definition, Scott and Bruce (1994) suggested that innovation involves adapting "products or processes from outside an organization" (p. 581). The definition provided by Scott and Bruce is particularly descriptive of the nine innovative practices that we examined in our research which are not typically considered part of standard K-12 curriculum or instructional outcomes. These innovations are designed to replicate an array of practices students will potentially use to solve problems in situations outside of the classroom and are structured to prepare students for the age of synthesis.

Teachers must believe in the efficacy of a change to their curriculum before they are able or willing to successfully implement it (Abrami, Poulsen, \& Chambers, 2004; Hegedus et al., 2014). Further research demonstrates the importance of support from schools and professional development provided by experts to facilitate teacher adoption of innovative practices (Frost, 2012; Tan \& Leong, 2014). Our research addresses these considerations. The lesson plans we studied were composed by the teachers following a week-long integrated STEM professional development (PD) designed to enhance their knowledge on a range of innovative instructional practices. Thus, we argue that the lesson plans provided a source of evidence for the extent to which teachers value educational innovations as meaningful ways of teaching and engaging their students in STEM learning.

\section{Method}

\section{Research questions}

Our overarching research question was, to what extent do teachers integrate educational innovations in their STEM lesson plans? To effectively explore how teachers incorporate educational innovations into their lesson plans we developed the following guiding research questions:

- What educational innovations do teachers include in their integrated STEM lesson plans?

- When included, how are teachers communicating plans for implementing educational innovations in their lesson plans?

We anticipated that our analysis of these lesson plans would reveal (a) how teachers plan on using educational innovations in their practice, (b) how the innovation is integrated in their STEM lesson plans, and (c) the frequency that teacher plans include educational innovations.

\section{Data sources}

The source of our data were the lesson plans that teachers created as a capstone assignment following their participation in a week-long integrated STEM PD program (i-STEM Lesson Plans, 2015). Participants agreed to make their lessons publicly available online for others to access and review. Over the course of the PD, participants were exposed to the nine educational innovations (see Table 1) such as hands-on or minds-on project-based learning, and engaging as students to develop deeper understanding of student-centered learning.

The nature of the exposure to the innovations ranged from brief presentations to full and explicit integration. For example, all institute participants participated in field trips (e.g., visits to a local technology company or a local water shed) to gain deeper understanding of the effectiveness of using place-based learning experiences to enhance student motivation and engagement in learning. All participants received a tablet computer that was intended to enhance their awareness of technology integration, and core STEM practices were integrated into all sessions, with rubric templates provided to the teachers to assess student engagement in STEM practices. The PD included an evening family science activity for all participants and focused on integrated STEM.

The participants' PD capstone activity was to adapt an extant lesson plan or compose an original lesson plan for teaching an integrated STEM lesson. The participants typically had time available at the PD to complete the plans, and were able to submit the plans up to two weeks after the PD program. Participants were instructed to develop lesson plans that utilized the nine innovative practices, which they had learned about in the PD. The participants were provided a lesson plan template; however, the participants were also encouraged to develop unique lesson that integrated multiple educational innovations. The teachers were encouraged to collaborate and share their work other participants; however, each participant was expected to submit a lesson plan. The PD leaders collected the lesson plans, which were then deidentified and made publicly accessible on the internet for others to review and use.

From the entire collection of participating teacher lesson plans (119 lessons), we focused on the lesson plans for Grades 3-5 for analysis, leaving us with a dataset of 39 lesson plans. We selected the Grade 3-5 band because of the expectation that elementary teachers will teach all subject areas, and the associated opportunities these teachers have to integrate curriculum (Fogarty, 1991; Gess-Newsome, 1999; Nixon \& Akerson, 
2004; Rogers \& Abell, 2013). Further, Grades 3-5 are a critical juncture for students developing foundational knowledge of and attitudes toward STEM (DeJarnette, 2012; Farenga \& Joyce, 1999). Although we recognize that the lesson plans were associated with the $\mathrm{PD}$, the focus on our research was the educational innovations that the teachers included in their lesson plans and not the influence of the PD on lesson plan development, as we did not have any pre-PD or non-PD teacher generated lesson plans for comparison.

\section{Analysis process}

In the first stage of our analysis, we developed a set of detailed explanations for the different levels of the nine educational innovations based on our collective professional experience with the associated instructional strategies (see Table 1). We then considered our prior research on simultaneous educational innovation implementation (Nadelson et al., 2015; Nadelson \& Seifert, 2016) and the research or frameworks of others on specific educational innovations (e.g., Schwab \& Brandwein, 1962) for implementation of inquiry to develop a rubric. Thus, our final rubric was designed to measure inclusion of the nine educational innovations, different levels of implementation of the innovations, and descriptions or definitions of the levels of implementation. In our development we relied on our extensive experience of generating rubrics for analyzing student. Our rubric development involved multiple iterations to assure effective descriptions of educational innovation implementation.

We designed our rubric based on our goal of identifying each of the nine educational innovation present in the lesson plans, and then rating the degree to which the innovation was planned for implementation or categorizing the process to be used in implementation. We established a 5-point scale to rate the presence of the nine innovations using a scale ranging from being completely absent to being fully implemented or integrated. For example, under the inclusion of instructional technology into an integrated STEM lesson plan, the scoring scale ranged from 1 (no technology) to 5 (essential to complete the lesson). To guide our rubric development for some innovations we considered the extant tools or models (e.g., Schwab and Brandwein's [1962] level of inquiry framework). We adapted and adopted these frameworks to effectively structure our rubrics for evaluating teacher generated lesson plans.

Using document analysis, we applied our rubric and evaluated the same subset of lesson plans independently to establish interrater reliability. We then compared and discussed our results and adjusted our scores based on our conversation. We repeated our individual analysis process and comparison process until we reached $90 \%$ agreement. Once we established interrater reliability we each evaluated a portion of the lesson plans. Following the lesson evaluation we compiled our rankings and determined the levels of implementation for our nine targeted innovations. We aligned our evaluations for level of implementation with the manner in which teachers had planned to use the innovation. In addition, we discussed the potential reasons for the overall representation of particular inclusion of an educational innovation within the lesson plans.

\section{Results}

\section{Educational innovations included in lesson plans}

We addressed our first research question (What educational innovations do teachers include in their integrated STEM lesson plans?) by determining the frequency of our codes for the level of implementation for each of our nine educational innovations. At the same time, we addressed our second research question (When included, how are teachers communicating plans for implementing educational innovations in their lesson plans?) by gathering exemplars of the levels of implementation communicated in the lesson plans. We present our results of frequencies and exemplars by educational innovation.

\section{Student-centered learning}

Our analysis of the teacher generated lesson plans revealed a variety of strategies to engage students in hands-on or mindson learning events (see Table 2). For instance, some lessons plans communicated approaches for engaging students in experiments which would likely result in different outcomes depending on student choices. Other lesson plans conveyed processes of creating situations that would allow students to

Table 2. Frequencies and exemplars of student-centered learning.

\begin{tabular}{|c|c|c|}
\hline $\begin{array}{l}\text { Levels of } \\
\text { implementation }\end{array}$ & Frequency & Level of implementation exemplar \\
\hline All teacher & 0 & N/A \\
\hline Mostly teacher & 14 & $\begin{array}{l}\text { In one example of a mostly teacher lesson, } \\
\text { students were charged with thinking of areas } \\
\text { on their school where bacteria might be found. } \\
\text { However, the teacher did the work of collecting } \\
\text { the samples and analyzing them to find and } \\
\text { identify bacteria. }\end{array}$ \\
\hline Shared equally & 10 & $\begin{array}{l}\text { In an activity on observing soundwaves, students } \\
\text { were tasked with building a tool (using } \\
\text { balloons, mirrors, and soup cans) that would } \\
\text { allow them to see the movement sound } \\
\text { causes. They were then given a series of tasks } \\
\text { to complete using the tool, and were told to } \\
\text { make note of their observations. Although } \\
\text { students had the freedom to record their own } \\
\text { observations, build their own tools, and } \\
\text { conduct their own experiments, they were } \\
\text { following clear and firm instructions designed } \\
\text { and delivered by the classroom teacher. }\end{array}$ \\
\hline Mostly student & 13 & $\begin{array}{l}\text { One activity showed students how to make } \\
\text { toothpaste, and gave them the tools and } \\
\text { materials to make their own in a variety of } \\
\text { flavors. Following the established procedure } \\
\text { but with the freedom to deviate from it, } \\
\text { students made their own toothpaste and } \\
\text { created an advertising campaign to sell their } \\
\text { product to others. }\end{array}$ \\
\hline All student & 2 & $\begin{array}{l}\text { These lesson plans came up with ideas for } \\
\text { providing structure while still giving students } \\
\text { control over the activity. For instance, one } \\
\text { lesson on the rock cycle not only allowed } \\
\text { students to create their own product, as in the } \\
\text { toothpaste lesson, but to have a hand in } \\
\text { designing the procedures of the experiment. } \\
\text { Students were allowed to collectively design } \\
\text { the parameters of the activity, use tools } \\
\text { themselves, make their own observations, and } \\
\text { draw their own conclusions while they } \\
\text { observed melting Starburst candies as } \\
\text { analogous to the rock cycle. }\end{array}$ \\
\hline
\end{tabular}


contribute to the design parameters of experiments. Although many lesson plans fell into the mostly teacher category, it should be noted that these teachers' plans reflected some desire to allow students to partially contribute to the design or implementation of the activity. None of the lesson plans we reviewed were coded as all teacher, indicating that all of the teachers' plans were at least to some degree student centered.

\section{Project-based learning}

We found a diverse representation of project-based learning in the lesson plans due to the range of projects that the teachers planned to teach (see Table 3). We perceive project-based learning as occurring when students conceive of, work on, and complete a project. Some of the projects conveyed in the teachers' lesson plans involved writing letters to the local newspaper, building models, and conducting science experiments. Six of the lesson plans did not include a project and another nine lesson plans indicated that students would observe a project being completed. The majority of the student-centered projects in the lesson plans were rather small in scope or short term. Only two lesson plans denoted long-term student-centered projects.

\section{Family involvement}

Although family involvement was one of the innovative practices reviewed in the STEM PD, the innovation was only detected in one of the reviewed lesson plans. In the Building a Boat lesson plan, students spent one week learning about boats through literature, exploration, and finally design when they were tasked with creating their own boat. The teacher communicated plans for family members to visit the classroom to observe the testing of the student-designed and constructed boats. No other lesson

Table 3. Frequencies and exemplars of project-based learning.

\begin{tabular}{|c|c|c|}
\hline $\begin{array}{l}\text { Project-based } \\
\text { learning }\end{array}$ & Frequency & Level of implementation exemplar \\
\hline No project & 6 & $\begin{array}{l}\text { Some lessons did not give students the } \\
\text { opportunity to work on any sort of project. } \\
\text { For instance, one lesson on birds asked that } \\
\text { students research the characteristics of } \\
\text { various birds, and then complete an } \\
\text { assessment on what they had learned. }\end{array}$ \\
\hline $\begin{array}{l}\text { Teacher } \\
\text { demonstrates } \\
\text { project }\end{array}$ & 9 & $\begin{array}{l}\text { In one lesson on bacteria, students contributed } \\
\text { ideas of where bacteria may be found, but } \\
\text { the teacher carries out and demonstrates to } \\
\text { students the procedures of identifying the } \\
\text { bacteria for students to observe. }\end{array}$ \\
\hline $\begin{array}{l}\text { Small project (part } \\
\text { of a larger } \\
\text { lesson) }\end{array}$ & 13 & $\begin{array}{l}\text { During one lesson, which is part of a larger unit } \\
\text { on elements, students completed the small } \\
\text { project of making models of various } \\
\text { elements. }\end{array}$ \\
\hline $\begin{array}{l}\text { Short-term or small- } \\
\text { scale project }\end{array}$ & 9 & $\begin{array}{l}\text { A lesson on chemical reactions gave students } \\
\text { the chance to conduct a short research } \\
\text { project in which they independently } \\
\text { produced and measured the reactions } \\
\text { between baking soda and vinegar. }\end{array}$ \\
\hline $\begin{array}{l}\text { Long-term or large- } \\
\text { scale project }\end{array}$ & 2 & $\begin{array}{l}\text { An activity that teaches basic rocketry tasks } \\
\text { students with designing the best possible } \\
\text { balloon rocket, but gives them the freedom } \\
\text { to decide how to do so. Students spent time } \\
\text { working on their own designs, and then a } \\
\text { competition was held in which students saw } \\
\text { who had designed the best performing } \\
\text { rocket. }\end{array}$ \\
\hline
\end{tabular}

plan contained any references to families, or included family presence in the classroom.

\section{Place-based learning}

Another educational innovation that was noticeably absent from the lesson plans was place-based learning. Although analyzing the lesson plans, we considered a community connections component as an opportunity for place-based learning (see Table 4). A few lesson plans conveyed creative ways of making community connections, such as the Mining for Gold lesson, which included an instructor presentation of mining in the students' home state before engaging the students in a mining related activity. In the Undoing Water Pollution lesson, the community connection is made through engaging students in writing letters about reducing neighborhood water pollution to their local papers. Fewer lessons plans involved strategies for engaging students in activities outside of the classroom such as the Name That River Attribute lesson, which included plans for students to visit a local river to apply their knowledge to identify various features of the river. The majority of lesson plans did not include any community connection activities and therefore did not attend to the educational innovation of place-based learning (see Table 4).

\section{Curriculum integration}

The integration of curriculum was conveyed in the lesson plans to a moderate degree (see Table 5). About $20 \%$ of the lesson plans did not include any plans for curriculum integration, focusing on single concepts and domains. The majority of the plans conveyed curriculum integration at a minimal to partial level by including plans for students to write and document their work (e.g., language arts), or measuring parameters and graphing results from an experiment (e.g., mathematics). However, the use of topics as a means of integrating curriculum were absent, although this was a primary focus on the integrated STEM professional development.

Table 4. Frequencies and exemplars of place-based learning.

\begin{tabular}{|c|c|c|}
\hline $\begin{array}{l}\text { Place-based } \\
\text { learning }\end{array}$ & Frequency & Level of implementation exemplar \\
\hline None & 26 & $\begin{array}{l}\text { Many lesson plans did not make reference or } \\
\text { take into consideration the community } \\
\text { students were living in. }\end{array}$ \\
\hline $\begin{array}{l}\text { Community } \\
\text { connections }\end{array}$ & 11 & $\begin{array}{l}\text { Some lesson plans, such as Mining for Gold, took } \\
\text { the opportunity to bring regional context into } \\
\text { the curriculum. In this instance, before } \\
\text { students learned about the process of mining } \\
\text { for gold, the teacher delivered a lesson about } \\
\text { gold mining in Idaho. }\end{array}$ \\
\hline $\begin{array}{l}\text { Community } \\
\text { speaker }\end{array}$ & 0 & $\begin{array}{l}\text { None of the lesson plans invited a community } \\
\text { speaker into the classroom. }\end{array}$ \\
\hline $\begin{array}{l}\text { Out of school in } \\
\text { the community } \\
\text { assignment }\end{array}$ & 1 & $\begin{array}{l}\text { Only gave students the opportunity to share } \\
\text { their knowledge with the broader } \\
\text { community. Undoing Water Pollution } \\
\text { required students to write a letter to their } \\
\text { local newspaper editor about the importance } \\
\text { of cleaning up water in their neighborhood. }\end{array}$ \\
\hline Field trip & 1 & $\begin{array}{l}\text { Only one lesson plan took students outside of } \\
\text { the classroom space. Name that River } \\
\text { Attribute brought students to a local river, } \\
\text { where they applied what they had learned } \\
\text { about river features in the classroom by } \\
\text { visiting and studying an actual river. }\end{array}$ \\
\hline
\end{tabular}


Table 5. Frequencies and exemplars of curriculum integration.

\begin{tabular}{|c|c|c|}
\hline $\begin{array}{l}\text { Curriculum } \\
\text { integration }\end{array}$ & Frequency & Level of implementation exemplar \\
\hline No integration & 8 & $\begin{array}{l}\text { Many lesson plans did not attempt to integrate } \\
\text { curriculum from outside content areas. }\end{array}$ \\
\hline Minimal integration & 11 & $\begin{array}{l}\text { A number of lesson plans added a brief } \\
\text { composition component to their lesson by } \\
\text { asking students to write up the results of } \\
\text { their project or experiment. }\end{array}$ \\
\hline Partial & 13 & $\begin{array}{l}\text { Many lessons, such as Baking Soda and Vinegar, } \\
\text { were able to identify a related content area } \\
\text { and easily integrate it into the lesson. For } \\
\text { instance, measuring and graphing chemical } \\
\text { reactions during a science experiment. }\end{array}$ \\
\hline $\begin{array}{l}\text { Large amount of } \\
\text { integration }\end{array}$ & 7 & $\begin{array}{l}\text { These lessons integrated skills between two or } \\
\text { more content areas evenly. For instance, } \\
\text { Mineral Identification asked students to } \\
\text { research and compose an ABC book on } \\
\text { different types of minerals. }\end{array}$ \\
\hline $\begin{array}{l}\text { Completely } \\
\text { integrated }\end{array}$ & 0 & None \\
\hline
\end{tabular}

\section{Instructional technology}

About half of the lesson plans (see Table 6) did not include use of technology and approximately $25 \%$ the planned technology use was passive for the students (e.g., watching a video or presentation). The remaining lessons, about $25 \%$, communicated more interactive to productive uses of technology such as the interactive use of software through simulations (e.g., the rock cycle) to the use of probeware for gathering data (e.g., computer

Table 6. Frequencies and exemplars of integration of instructional technology.

\begin{tabular}{|c|c|c|}
\hline $\begin{array}{l}\text { Integration of } \\
\text { instructional technology }\end{array}$ & Frequency & Level of implementation exemplar \\
\hline No technology & 18 & $\begin{array}{l}\text { Many teachers did not integrate } \\
\text { technology into their lesson plan. }\end{array}$ \\
\hline $\begin{array}{l}\text { Minimal or passive use of } \\
\text { technology }\end{array}$ & 9 & $\begin{array}{l}\text { These lesson plans integrated only a small } \\
\text { amount of technology, or technology } \\
\text { that was not interactive. For instance, } \\
\text { Balloon Rockets provides students with } \\
\text { a Bill Nye the Science Guy video to } \\
\text { watch before beginning their work. }\end{array}$ \\
\hline $\begin{array}{l}\text { Partial integration of } \\
\text { technology }\end{array}$ & 5 & $\begin{array}{l}\text { These lessons gave technology a larger } \\
\text { role, but it wasn't necessarily key to } \\
\text { completing the lesson. Making Rocks } \\
\text { Using the Rock Cycle identified an } \\
\text { interactive web game on the rock cycle } \\
\text { for students to play before beginning } \\
\text { the central lesson to introduce them to } \\
\text { the concepts. }\end{array}$ \\
\hline $\begin{array}{l}\text { Large amount of } \\
\text { technology } \\
\text { integration }\end{array}$ & 3 & $\begin{array}{l}\text { Technology was an important part of } \\
\text { these lessons. In Watch What Goes } \\
\text { Down That Drain, students conducted } \\
\text { research on the internet in addition to } \\
\text { completing hands-on activities to learn } \\
\text { more about chemicals and pollution. } \\
\text { They synthesized and demonstrated } \\
\text { what they had learned by creating a } \\
\text { presentation in iMovie. }\end{array}$ \\
\hline $\begin{array}{l}\text { Complete integration of } \\
\text { instructional } \\
\text { technology }\end{array}$ & 4 & $\begin{array}{l}\text { Technology was a vital component of } \\
\text { lesson plans in this category. In Solar } \\
\text { Ovens, students learn about solar } \\
\text { power and then construct their own } \\
\text { solar oven. They measure the efficacy } \\
\text { of their design by monitoring the } \\
\text { temperature of their oven using digital } \\
\text { thermometers and accompanying } \\
\text { software, and compare their results to } \\
\text { the results of their peers. }\end{array}$ \\
\hline
\end{tabular}

interfaced thermometers for monitoring temperature). It is important to note that technology was explicitly emphasized in the PD with the use of the device modeled by the instructors and each participant receiving a tablet computer that they used throughout the week-long event.

\section{Inquiry}

Our analysis for the inclusion of inquiry into the lesson plans revealed somewhat of a normal distribution with the least frequent implementation levels occurring at the low and high ends of our scale (see Table 7). Although about half of the lessons communicated a prescribed level of inquiry, level 0 , and about a third were at levels 1 and 2 (Schwab \& Brandwein, 1962). Very few of the participants drafted lessons at level 3 inquiry of our analysis of student self-directed levels of inquiry (Schwab \& Brandwein, 1962).

\section{1st century skills}

Our analysis of the lesson plans revealed that the majority of the teachers attended to at least one or multiple 21 st century skills, with only seven lesson plans lacking an explicit inclusion of or attention to 21st century skills (see Table 8). Most lesson plans included an achievable number (1-5) of 21st century skills. However, a few of the lesson plans conveyed details for engaging student in as many as ten skills. An examination of the frequency of the specific 21st century skills included in the lessons revealed collaboration and communication were most

Table 7. Frequencies and exemplars of inquiry.

\begin{tabular}{|c|c|c|}
\hline Inquiry & Frequency & Level of implementation exemplar \\
\hline No inquiry & 3 & $\begin{array}{l}\text { Questioning and investigation were not part of } \\
\text { these lesson plans. Students learned by } \\
\text { completing book work. For instance, in one } \\
\text { lesson on birds, students learned about birds } \\
\text { by doing research, writing an expository essay, } \\
\text { and taking a test. }\end{array}$ \\
\hline $\begin{array}{l}\text { Prescribed } \\
\text { inquiry } \\
\text { (level 0) }\end{array}$ & 19 & $\begin{array}{l}\text { Investigation and questioning were a part of } \\
\text { these lessons in the form of prescribed inquiry. } \\
\text { Students had no room to make decisions or } \\
\text { ask their own questions. For instance, in a } \\
\text { lesson on bacteria, students collected bacteria } \\
\text { samples for their teacher to analyze to learn } \\
\text { more about the bacteria in their own school } \\
\text { building. }\end{array}$ \\
\hline $\begin{array}{l}\text { Student can } \\
\text { make some } \\
\text { decisions } \\
\text { (level 1) }\end{array}$ & 8 & $\begin{array}{l}\text { Lesson plans such as Energy, Light, and Heat give } \\
\text { students room to make some decisions during } \\
\text { the lesson. In this example, students were } \\
\text { given an ice cube and, as a group, determined } \\
\text { the fastest way to melt it during a larger } \\
\text { lesson on energy. }\end{array}$ \\
\hline $\begin{array}{l}\text { Student makes } \\
\text { most } \\
\text { decisions } \\
\text { (level 2) }\end{array}$ & 7 & $\begin{array}{l}\text { Lesson plans in this category allowed students to } \\
\text { make many decisions in the activity. In Build a } \\
\text { Boat, students were given background } \\
\text { knowledge on boats and buoyancy, and were } \\
\text { then allowed to design their own boat with } \\
\text { periodic feedback from parents, teacher, and } \\
\text { peers. }\end{array}$ \\
\hline $\begin{array}{l}\text { Student makes all } \\
\text { decisions } \\
\text { (level 3) }\end{array}$ & 2 & $\begin{array}{l}\text { Students were allowed to set their own guidelines } \\
\text { and work in independent groups in activities } \\
\text { such as Paste With a Taste. As groups, students } \\
\text { decided what kind of toothpaste they would } \\
\text { like to make, how to make it taste the best, } \\
\text { and how to market it to others. }\end{array}$ \\
\hline
\end{tabular}


Table 8. 21st century skills frequency, and exemplars.

\begin{tabular}{ccc}
\hline 21st century skills & Frequency & Level of implementation exemplar \\
\hline $\begin{array}{c}\text { Not applied in the } \\
\text { lesson (0 skills) }\end{array}$ & 7 & $\begin{array}{c}\text { In Bird Watching, students did not need to } \\
\text { collaborate, problem solve, or think } \\
\text { critically to complete the activity. }\end{array}$ \\
$\begin{array}{c}\text { Applied very little } \\
\text { (1-2 skills) }\end{array}$ & 16 & $\begin{array}{c}\text { Students worked on their communication } \\
\text { skills when completing an activity on the } \\
\text { water cycle, but didn't use any other 21st } \\
\text { century skills. }\end{array}$ \\
$\begin{array}{c}\text { Applied somewhat } \\
\text { (3-5 skills) }\end{array}$ & 10 & $\begin{array}{l}\text { In one activity on rocketry, students relied on } \\
\text { creativity, collaboration, and critical } \\
\text { thinking to design their own balloon } \\
\text { rockets with their peers, and to win a } \\
\text { competition using them. }\end{array}$ \\
Applied a great deal \\
(6-8 skills) & 4 & $\begin{array}{l}\text { Students relied somewhat on many 21st } \\
\text { century skills such as computing, } \\
\text { competency, and collaboration when } \\
\text { designing and evaluating their own solar } \\
\text { ovens. }\end{array}$ \\
Applied extensively \\
(9-10 skill)
\end{tabular}

frequent, whereas computational thinking and competency were least frequent (see Figure 1).

\section{Core STEM practices}

As we examined the inclusion of core STEM practices within the teachers' lesson plans, we found that all but one plan explicitly included activities that required the students to engage in STEM practices (see Table 9). The distribution of the inclusion of core STEM practices was nearly equal from a few to all core STEM practices. In our examination of the specific practices that the teachers included in their plans, we found questioning to occur most frequently and computational thinking to occur least frequently (see Figure 2).

\section{Discussion and implications}

The goal of our research was to examine the level to which educational innovations where included in lesson plans generated by teachers who attended a week-long summer PD focusing on teaching and learning integrated STEM. We examined the lesson plans generated by third- to fifth-grade teachers. Teachers who teach all subjects and have the same students all day have greater flexibility in their curricular and instructional choices, which we posited is more likely to lead to inclusion of educational innovations in their lesson plans.

Considered as a whole, the teachers tended to be moderate in their inclusion or integration of educational innovations in their lesson plans, with the exception of family involvement in learning, which teachers largely neglected. Although educational innovations were explicit in the PD program (such as use of field trips to support place-based learning), other innovations (e.g., problem- and project-based learning) were more implicit, which may have not adequately activated the teachers' attention toward the innovations. It is possible that the lack of explicit attention to certain educational innovations constrained attention toward these innovations in the lesson plans. However, all of the PD participants were involved in field trips, an explicit component of the PD designed to emphasize placebased learning, and yet few teachers included any reference to place in their lesson plans. We suggest that it is a lack of models and experience with educational innovations that limits teachers' ability to develop lessons that integrate the innovations. We speculate that the lack of teachers' inclusion of educational innovations in their lessons reflects their views and experience with education as well as their curricular and instructional choices. Consequently, we argue that the limited representation of innovations in the teachers' lesson plans is likely to be paralleled in practice; suggesting that for educators to consider implementing innovations, they need support and experience teaching and learning using the educational innovations.

Some of the educational innovations that were strongly represented in our dataset (e.g., project-based learning-a foundational skill required for completing a science project) are practices that may naturally lend themselves to STEM instruction. Therefore, we posit that the inclusion of some educational innovations are less likely to require teachers to make major adjustments to the curricular and instructional choices; and

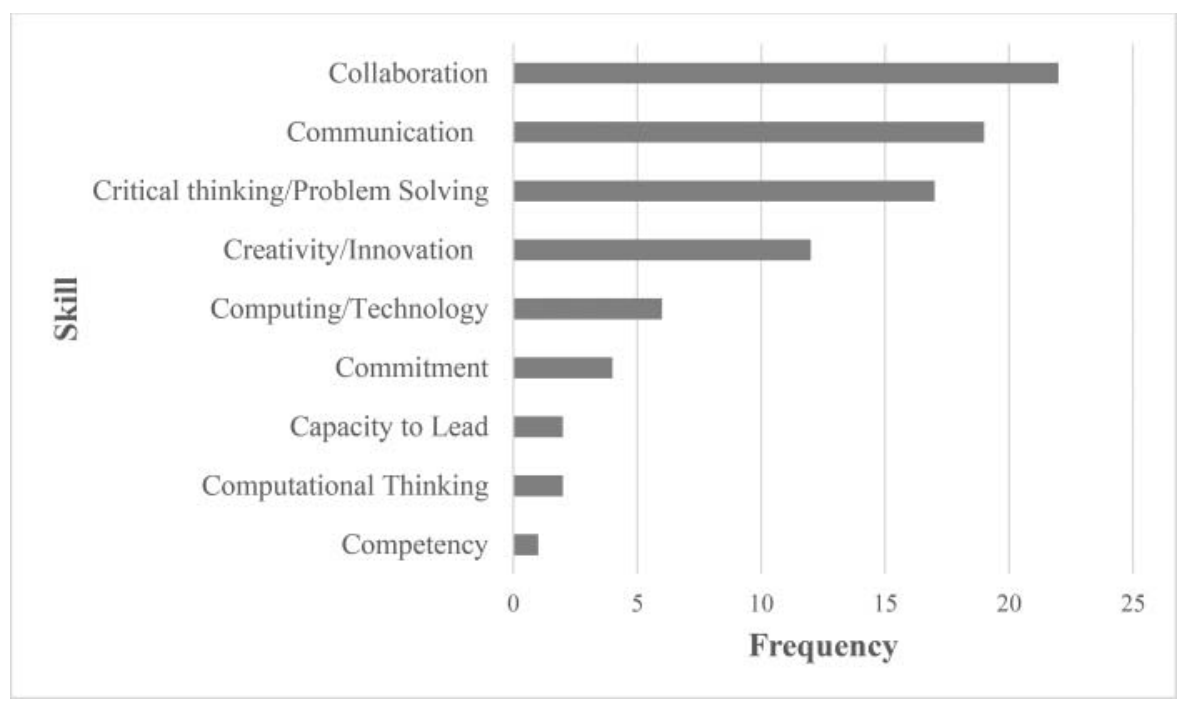

Figure 1. The frequency of 21st century skill inclusion in the lesson plans. 
Table 9. Core STEM practices frequency and exemplars.

\begin{tabular}{|c|c|c|}
\hline Core STEM practices & Frequency & Level of implementation exemplar \\
\hline $\begin{array}{l}\text { Not applied in the } \\
\text { lesson ( } 0 \text { practices) }\end{array}$ & 1 & $\begin{array}{l}\text { One lesson on the water cycle, intended for } \\
\text { ELL students, did not require students to } \\
\text { use any Core STEM practices. }\end{array}$ \\
\hline $\begin{array}{l}\text { Applied very little (1-2 } \\
\text { practices) }\end{array}$ & 14 & $\begin{array}{l}\text { Students rely a little on questioning and } \\
\text { modeling strategies in one creative } \\
\text { introduction to the water cycle, but these } \\
\text { skills are not taught or practiced in depth. }\end{array}$ \\
\hline $\begin{array}{l}\text { Applied somewhat (3- } \\
5 \text { practices) }\end{array}$ & 9 & $\begin{array}{l}\text { Students ask some questions and conduct a } \\
\text { short investigation by picking apart and } \\
\text { analyzing mock rocks to learn more } \\
\text { about minerals. }\end{array}$ \\
\hline $\begin{array}{l}\text { Applied a great deal } \\
\text { (6-8 practices) }\end{array}$ & 7 & $\begin{array}{l}\text { In Water is Everywhere, students relied } \\
\text { somewhat on a number of Core STEM } \\
\text { practices such as explaining, arguing, } \\
\text { questioning, and problem solving in this } \\
\text { activity on global water supplies. }\end{array}$ \\
\hline $\begin{array}{l}\text { Applied extensively } \\
\text { (9-10 practices) }\end{array}$ & 8 & $\begin{array}{l}\text { One activity on mineral identification relies } \\
\text { on questioning, investigating, and } \\
\text { explaining in depth as students draw } \\
\text { from their surroundings, the internet, and } \\
\text { other resources to learn about and } \\
\text { explain different types of minerals. }\end{array}$ \\
\hline
\end{tabular}

that they would typically use the innovations to teach STEM related concepts and content. For instance, science experiments have long been a staple of the traditional science classroom. Although traditional experiments such as building a model or combining chemicals might not in themselves be exemplars of inquiry or student-centered instruction, we argue that they have strong foundations in project-based learning. The extension from a teacher-demonstrated project and a small-scale project may have been a logical one for teachers who attended the PD. Deeper exploration of the association between the educational innovations that teachers use with higher frequency and those they might include in their lesson plans is an excellent direction for future research.

Three of the nine innovations we examined, integration of curriculum, integration of instructional technology, and inquiry, were represented moderately in the lesson plans. One potential reason that they might not be represented as frequently as project-based learning or student-centered learning is that they have not traditionally been as emphasized in education in general (Oleson \& Hora, 2014). For example, whereas curriculum integration may be of interest, the process is effortful, requires coordination and communication, and necessitates thinking about teaching and learning in nontraditional ways. Traditional school structures, such as teaching content areas separately, may stifle potential for considering teaching using some educational innovations. Although the development of new STEM learning standards (e.g., the Next Generation Science Standards and Common Core State Standards for Mathematics) to include practices, as well as content, may act as a catalyst to increase teacher adoption and implementation of some educational innovations (Next Generation Science Standards, 2016). The extent to which teachers are implementing new learning standards and their consideration of educational innovations is likely a fruitful direction for future research.

Although teachers were not surveyed as to their reasons for including or not including specific practices, prior research leads us to speculate that some educational innovations were noticeably absent because teachers tend to teach the way they were taught (Oleson \& Hora, 2014), which likely influences their instructional and curricular choices. As many of the educational innovations we studied in our research are relatively unique to teaching practices, it is possible that the teachers who composed the lesson plans we examined were not exposed to them as students. It is likely the teachers had no personal examples of or experience with these educational innovations and therefore did not attend to them in their lesson development. We contend that without experience or models of the implementation of the educational innovations, teachers are less likely to conceive of how they might integrate the innovations in their lessons (Guskey, 2002).

Another reason some educational innovations might have been left out is the perceived feasibility of the innovation. For instance, when teachers consider the notion of place-based learning, they might have understood implementing the innovation to necessarily require field trips. Educational field trips can be complicated endeavors, requiring substantial planning, commitments of time, cost, and sometimes risk. Thus, many teachers may discount place-based learning due to perceptions of complexity and cost, without consideration of other ways of engaging students in the innovative practice. Similarly, bringing family members into the classroom can be a time consuming, stressful, and perceived as threatening for many teachers

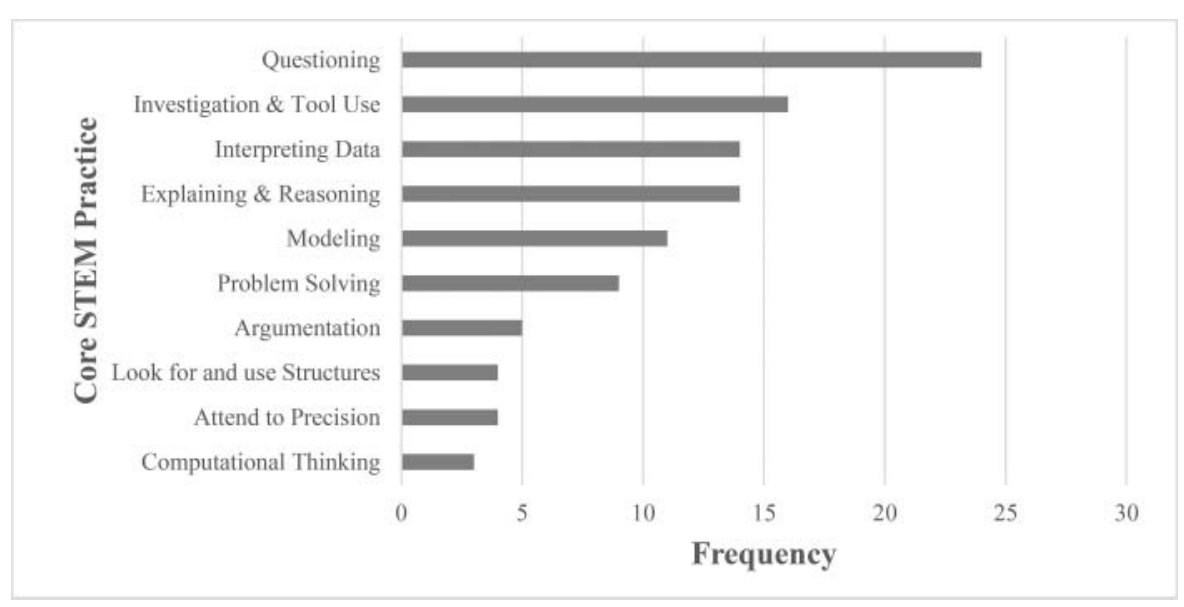

Figure 2. Inclusion of core STEM practices in the lesson plans. 
(Hargreaves, 2001). Although there are many ways in which teachers may involve families in their children's education that don't involve being in the classroom (for instance, asking family members to contribute to curriculum and assignments from home, or requiring students to interview family members), teachers did not communicate these opportunities in their lesson plans. Again, we speculate that it is likely that teachers lack experience or models for the range of ways in which they might involve families in students' learning, and therefore do not consider these options in the lesson development. Perhaps more PD needs to be offered to engage teachers in experiencing the many ways they can bridge the gap between classroom and community without needing to organize an outing or day to include families in students' learning. Gaining a deeper understanding of the perceptions of teachers regarding family involvement in learning is an important and potentially critical direction for research.

It is worth noting that a connection exists between studentcentered and project-based learning that might have made it easy for teachers to integrate the two in their lesson plans. The relatively close association between student-centered learning and project-based learning may explain why these two practices were among the most represented in our dataset. Teachers who assign students a project typically give the students the responsibility for some level of decision making, sometimes expecting students to take full responsibility for their projects. The natural integration of these two practices and their high frequency of presence in the lesson plans suggest that with a well-crafted teacher PD that identifies and emphasizes similar natural connections between or among educational innovations, teachers may be more likely to consider the options in their lessons.

One obvious area of deficit in the lesson plans was attention toward computational thinking and reasoning. With the increased need for computer scientists and expanded attention toward computing in society, there is a need to explore ways to raise teachers' knowledge and integration of this practice and the related 21st century skills in their curricular and instructional choices (Dede, 2010; Larson \& Miller, 2011). Exploring ways to enhance teachers' understanding and awareness of how to effectively integrate computational thinking across the curriculum is an excellent direction for future research.

\section{Limitations}

One limitation of our study is that teachers tend to write lesson plans loosely, providing limited details and considering them to be guides for themselves (Kagan \& Tippins, 1992). They may write the plans in such a way that does not detail the entire conception of the lesson because they understand the processes and goals they intend to reach and therefore do not perceive the need for greater detail. On the other hand, when others read the lesson plans, they may perceive gaps in details that the teacher generating the plan did not realize were missing or perceive the details to be unnecessary. We attempted to mitigate this limitation by selecting lesson plans that were generated using a template and therefore we expected to be rather uniform and include some of the same information. Still, it is possible the lesson plans we examined were not accurate representations of what the teachers intended to teach or even convey to others considering their lessons. Regardless, we perceived the lesson plans to be consistent with and reflective of traditional approaches to teaching and learning, and therefore can be arguably valid proxies of teacher consideration and potential for implementing educational innovations. Interviewing teachers about their lesson plans and intentions to teach using innovations is an excellent direction for future research.

Another limitation of our study is that we are unable to determine why teachers may have addressed some innovative practices but not others. As we discussed, it is possible that teachers did not perceive the feasibility of some of the practices, such as family or community involvement. But the potential explanations of their curricular and instructional choices are numerous. It could be that the teachers tended to have individual experiences that lead them to consider some innovations over others. Thus, teachers could be drawing from their personal experiences to come to the conclusion that some innovative practices are not feasible or desirable. A deeper understanding of why certain educational innovations were represented less frequently than others could inform the design of PD to enhance teachers' recognition of specific strategies that may be effective for integrating educational innovations in their lessons.

A third limitation is the lesson plans we examined were from teachers attending one PD program in one region of the United States. It may be possible that other groups of third- to fifth-grade teachers have different ideas about using educational innovations to teach integrated STEM lessons. Thus, a replication of our work in other locations and with different groups of Grade 3-5 teacher-generated lesson plans is a potentially fruitful direction for future research.

\section{Conclusions}

Lesson plans are a common document that teachers use to guide their instructional and curricular choices. Therefore, we considered teacher generated lesson plans as a reflection of the potential for teachers to consider educational innovations as part of their instructional and curricular choices. In our analysis of teacher generated lesson plans we found a wide range of communicated level of educational innovations, and for the most part moderate levels of innovation consideration. Our research suggests that more PD and support may be needed to prepare teachers to consider educational innovations in their lessons. Given the needs of age of synthesis students, the use of educational innovations is critical for preparing students for their future.

\section{References}

Abd-El-Khalick, F., Boujaoude, S., Duschl, R., Lederman, N. G., MamlokNaaman, R., Hofstein, A., ... Tuan, H. L. (2004). Inquiry in science education: International perspectives. Science Education, 88, 397-419.

Abrami, P. C., Poulsen, C., \& Chambers, B. (2004). Teacher motivation to implement an educational innovation: Factors differentiating users and non-users of cooperative learning. Educational Psychology, 24, 201-216.

Anderson, R. D. (2002). Reforming science teaching: What research says about inquiry. Journal of Science Teacher Education, 13(1), 1-12.

Bell, S. (2010). Project-based learning for the 21st century: Skills for the future. The Clearing House, 83(2), 39-43. 
Belmont, J. M. (1989). Cognitive strategies and strategic learning: The socio-instructional approach. American Psychologist, 44, 142-148.

Berkowitz, T., Schaeffer, M. W., Maloney, E. A., Peterson, L., Gregor, C., Levine, S. C., \& Beilock, S. L. (2015). Math at home adds up to achievement in school. Science, 350, 196-198.

Binkley, M., Erstad, O., Herman, J., Raizen, S., Ripley, M., Miller-Ricci, M., \& Rumble, M. (2012). Defining 21st century skills. In P. Griffin \& E. Care (Eds.), Assessment and teaching of 21st century skills (pp. 17-66). Amsterdam, the Netherlands: Springer.

Brown, D. S. (1988). Twelve middle-school teachers' planning. The Elementary School Journal, 89, 69-87.

Brown, D. S. (1993). Descriptions of two novice secondary teachers' planning. Curriculum Inquiry, 23, 63-84.

Brown S. L., \& Melear, C. T. (2006). Investigation of secondary science teachers' beliefs and practices after authentic inquiry-based experiences. Journal of Research in Science Teaching, 43(9), 938-962.

Cai, S. (2011). The age of synthesis: From cognitive science to converging technologies and hereafter. Chinese Science Bulletin, 56, 465-475.

Dede, C. (2010). Comparing frameworks for 21st century skills. In J. Bellanca \& R. Brandt (Eds.), 21st century skills: Rethinking how students learn (pp. 51-76). Bloomington, IN: Solution Tree Press.

DeJarnette, N. (2012). America's children: Providing early exposure to STEM (science, technology, engineering and math) initiatives. Education, 133, 77-84.

Dierking, L. D., \& Falk, J. H. (1994). Family behavior and learning in informal science settings: A review of the research. Science Education, 78, $57-72$.

Farenga, S. J., \& Joyce, B. A. (1999). Intentions of young students to enroll in science courses in the future: An examination of gender differences. Science Education, 83, 55-75.

Fogarty, R. (1991). Ten ways to integrate curriculum. Educational Leadership, 49(2), 61-65.

Frost, D. (2012). From professional development to system change: Teacher leadership and innovation. Professional Development in Education, 38, 205-227.

Gess-Newsome, J. (1999). Guest editorial: Delivery models for elementary science instruction: a call for research. Electronic Journal of Science Education, 3(3).

Gruenewald, D. A., \& Smith, G. A. (Eds.). (2014). Place-based education in the global age: Local diversity. New York, NY: Routledge.

Guskey, T. R. (2002). Professional development and teacher change. Teachers and Teaching: Theory and Practice, 8, 381-391.

Hall, C. W. (1995). The age of synthesis. New York, NY: Peter Lang

Hannafin, M. J., \& Land, S. M. (1997). The foundations and assumptions of technology-enhanced student-centered learning environments. Instructional Science, 25, 167-202.

Hannafin, M. J., \& Land, S.M. (2012). Student-centered learning. In N. M. Seel, (Ed), Encyclopedia of the sciences of learning (pp. 3211-3214). Freiburg, Germany: Springer.

Hargreaves, A. (2001). Emotional geographies of teaching. Teachers College Record, 103, 1056-1080.

Hegedus, S. J., Dalton, S., Roschelle, J., Penuel, W., Dickey-Kurdziolek, M., \& Tatar, D. (2014). Investigating why teachers reported continued use and sharing of an educational innovation after the research has ended. Mathematical Thinking and Learning, 16, 312-333.

Hiatt-Michael, D. (2001). Preparing teachers to work with parents (ED460123). Washington, DC: Eric Clearinghouse on Teaching and Teacher Education.

Honey, M., Pearson, G., \& Schweingruber, H. (Eds.). (2014). STEM Integration in K-12 Education: Status, Prospects, and an Agenda for Research. Washington, DC: National Academies Press.

i-STEM 2015 Lesson Plans. (2015). Welcome to the 2015 i-STEM lesson plans page. Retrieved from: https://sites.google.com/a/boisestate.edu/istem-2015-lesson-plans/

Inan, F. A., \& Lowther, D. L. (2010). Factors affecting technology integration in K-12 classrooms: A path model. Educational Technology Research and Development, 58, 137-154.

Jacobs, C. L., Martin, S. N., \& Otieno, T. C. (2008). A science lesson plan analysis instrument for formative and summative program evaluation of a teacher education program. Science Education, 92, 1096-1126.
Kagan, D. M., \& Tippins, D. J. (1992). The evolution of functional lesson plans among twelve elementary and secondary student teachers. The Elementary School Journal, 94, 477-489.

Kirkwood, A., \& Price, L. (2005). Learners and learning in the twenty-first century: What do we know about students' attitudes towards and experiences of information and communication technologies that will help us design courses? Studies in Higher Education, 30, 257-274.

Krajcik, J. S. and Blumenfeld, P. (2006). Project-based learning. In R. K. Sawyer (Ed.), The Cambridge handbook of the learning sciences (pp. 317-334). New York, NY: Cambridge University Press.

Larson, L. C., \& Miller, T. N. (2011). 21st century skills: Prepare students for the future. Kappa Delta Pi Record, 47, 121-123.

Liu, Y., \& Szabo, Z. (2009). Teachers' attitudes toward technology integration in schools: A four-year study. Teachers and Teaching: Theory and Practice, 15, 5-23.

Martinez, S. L., \& Stager, G. (2013). Invent to learn: Making, tinkering, and engineering in the classroom. Torrance, CA: Constructing Modern Knowledge Press.

McCutcheon, G. (1980). How do elementary school teachers plan? The nature of planning and influences on it. The Elementary School Journal, $81,4-23$.

Messmann, G., \& Mulder, R. H. (2011). Innovative work behaviour in vocational colleges: Understanding how and why innovations are developed. Vocations and Learning, 4(1), 63-84.

Moore, J. A., Treahy, D., Chao, C. C., \& Barab, S. A. (2000). The Internet learning forum: Designing and building an online community of practice. Society for Information Technology \& Teacher Education International Conference, 2000, 2208-13.

Nadelson, L. S. \& Seifert A. L. (2014). Integrated STEM, 21st century skills, and place-based learning: A state wide plan for the i-STEM professional development and research initiative. Washington, DC: USDOE MSP Conference.

Nadelson, L. S., Seifert, A. L. \& Chang, C. (2013). The perceptions, engagement, and practices of teachers seeking professional development in place-based integrated STEM. Teacher Education and Practice, 26, 242-265.

Nadelson, L. S., Seifert, A. L., Moll, A. \& Coats, B. (2012). i-STEM summer institute: An integrated approach to teacher professional development in STEM. Journal of STEM Education: Innovation and Outreach, 13, 69-83.

Nadelson, L. S., Seifert, A. L. \& Hendricks, K. (2015). Are we preparing the next generation? K-12 teacher knowledge and engagement in teaching core STEM practices. Proceedings of the Annual Meeting of the American Society Engineering Education, 122.

Nadelson, L. S., Seifert, A. L., Sias, C.M. (2015). To change or not to change: Indicators of K-12 teacher engagement in innovation practices. International Journal of Innovation in Education, 3, 45-61.

Nadelson, L. S., \& Seifert, A. L. (2016). Putting the pieces together: A model of K-12 teachers' innovation implementation behaviors. Journal of Research in Innovative Teaching, 9, 47-67.

Nadelson, L. \& Seifert, A. (in press). Integrated STEM defined: Contexts, challenges, and the future. The Journal of Educational Research.

National Governors Association Center for Best Practices \& Council of Chief State School Officers. (2010). Common core state standards for mathematics. Washington, DC: Authors.

NGSS Lead States. 2013. Next Generation Science Standards: For states, by states. Washington, DC: National Academies Press.

Nixon, D., \& Akerson, V. L. (2004). Building bridges: Using science as a tool to teach reading and writing. Educational Action Research, 12, $197-218$.

Oleson, A., \& Hora, M. T. (2014). Teaching the way they were taught? Revisiting the sources of teaching knowledge and the role of prior experience in shaping faculty teaching practices. Higher Education, 68, 29-45.

Partnership for 21st Century Learning. (2016). Framework for 21st century learning. Retrieved from: http://www.p21.org/storage/documents/docs/ P21_Framework.pdf

Pearlman, B. (2010). Designing new learning environments to support 21st century skills. In J. Bellanca \& R. Brandt (Eds.), 21st century skills: Rethinking how students learn (pp 116-147). Bloomington, IN: Solution Tree Press. 
Rae, D. \& Nadelson, L. S. (under review). What are you going to do with that digital camera? A snapshot of educators' perspectives and practices with instructional technology. Manuscript submitted for publication.

Robins, J. (2000). K-12 collaboratories. Bulletin of the American Society for Information Science and Technology, 26(3), 8-10.

Rogers, M. A. P., \& Abell, S. K. (2013). Connecting with other disciplines. In D. Hanuscin \& M. A. Rogers (Eds.), Perspectives: Research \& tips to support science education, K-6 (pp. 39-41). Arlington, VA: National Science Teachers Association.

Rotherham, A. J., \& Willingham, D. T. (2010). "21st-Century” skills. American Educator, 34, 17-20.

Saavedra, A. R., \& Opfer, V. D. (2012). Learning 21st-Century skills requires 21st-Century teaching. Phi Delta Kappan, 94(2), 8-13.

Schwab, J. J., \& Brandwein, P. F. (1962). The teaching of science: The teaching of science as enquiry. Cambridge, MA: Harvard University Press.

Scott, S. G., \& Bruce, R. A. (1994). Determinants of innovative behavior: A path model of individual innovation in the workplace. Academy of Management Journal, 37, 580-607.
Staples, K. E., \& Diliberto, J. A. (2010). Guidelines for successful parent involvement working with parents of students with disabilities. Teaching Exceptional Children, 42(6), 58-63.

Tan, A. L., \& Leong, W. F. (2014). Mapping curriculum innovation in STEM schools to assessment requirements: Tensions and dilemmas. Theory Into Practice, 53, 11-17.

Next Generation Science Standards. (2016). The Need for Standards Retrieved August 24, 2016, from http://www.nextgenscience.org/needstandards

Thurlings, M., Evers, A. T., \& Vermeulen, M. (2015). Toward a model of explaining teachers' innovative behavior: A literature review. Review of Educational Research, 85, 430-471.

Trilling, B., \& Fadel, C. (2009). 21st century skills: Learning for life in our times. New York, NY: Wiley.

Wysession, M. W. (2015). Next Generation Science Standards: Preparing students for careers in energy-related fields. The Leading Edge, 34, 1166-1176.

Yinger, R. J. (1980). A study of teacher planning. The Elementary School Journal, 80, 107-127. 